\title{
Ruhsal Bozukluğu Olan Bireye Sahip Ailelerin Psikolojik Dayanma Güçleri İle Öfke ve Öfke İfade Tarzlarının İncelenmesi
}

\section{Examination of Psychological Resilience, Anger and Anger Expression Styles in Families of Individuals with Psychiatric Disorders}

\author{
${ }^{1}$ Gülgün DURAT, ${ }^{1}$ Gümrah Duygu ÇULHACIK, ${ }^{1}$ Bedia TARSUSLU, ${ }^{2}$ Atila EROL, \\ ${ }^{3}$ Zuhal EDİN, ${ }^{4}$ Merve KELEŞ
}

\begin{abstract}
${ }^{1}$ Sakarya Üniversitesi Sağlık Bilimleri Fakültesi, Hemşirelik Bölümü, Psikiyatri Hemşireliği ABD. Sakarya, Türkiye. ${ }^{2}$ Sakarya Üniversitesi Tıp Fakültesi Dahili Tıp Bilimleri Bölümü Ruh Sağlığı ve Hastalıkları ABD. Sakarya, Türkiye. ${ }^{3}$ İstanbul Üniversitesi Çapa Tıp Fakültesi Hastanesi. Sakarya, Türkiye.

${ }^{4}$ Koşuyolu Medipol Hastanesi. İstanbul, Türkiye.
\end{abstract}

Gülgün Durat: https://orcid.org/0000-0002-9889-3622

Gümrah Duygu Çulhacık: https://orcid.org/0000-0002-6620-3674

Bedia Tarsuslu: https://orcid.org/0000-0002-4606-2843

Atila Erol: https://orcid.org/0000-0001-9783-8405

Zuhal Edin: https://orcid.org/0000-0003-2857-0665

Merve Keleş: https://orcid.org/0000-0002-9169-1892

\section{ÖZ}

Amaç: Ruhsal bozukluğu olan hasta ile yaşama ve onun bakımını sağlama baş edilmesi güç bir durumdur. Çalışmada psikiyatrik tedavi alan hastaların yakınlarının, psikolojik dayanma güçleri ile öfke ve öfke ifade tarzlarının, sosyo-demografik değişkenler ve şiddete maruz kalma gibi yaşam olayları arasındaki ilişkinin incelenmesi amaçlanmıştır.

Materyal ve Metot: Araştırma, 13 Şubat- 3 Nisan 2017 tarihleri arasında, bir Eğitim ve Araștırma Hastanesinin psikiyatri kliniklerinde (Kadın, Erkek Psikiyatri Klinikleri) yatarak veya ayaktan tedavi gören 200 hastanın bakımı ve izleminde sorumluluk alan yakınlarının katılımıyla gerçekleştirilmiştir. Veriler, Kişisel Bilgi Formu, Kendini Toparlama Gücü Ölçeği (KTG) ve Sürekli Öfke ve Öfke Ífade Ölçeği (SÖÖTÖ) kullanılarak toplanmıştır.

Bulgular: Erkeklerin kadınlara göre öfke dışa vurum puanlarının anlamlı bir şekilde daha yüksek olduğu saptanmıştır. Daha önce şiddete maruz kalanların, kalmayanlara göre KTG ve öfke kontrol puan ortalamaları daha düşük ve sürekli öfke, öfke dişa vurum, öfke içe vurum puan ortalamaları daha yüksektir. KTG ile öfke kontrol puanları arasında pozitif yönde ilişki bulunmuştur $(\mathrm{p}<0,05)$.

Sonuç: Araştırma sonuçları, psikiyatrik bozukluğu olan hastaların yakınlarında cinsiyetin ve daha önce şiddete maruz kalmanın, sonraki dönemlerde öfke kontrolü, zorluklar karşısında baş edebilme ve kişinin öfkesini ifade ediş biçimi üzerinde etkili olduğunu göstermiştir. Ayrıca kendini toparlama güçleri yüksek olan bireylerin öfke kontrolünün de yüksek olduğu söylenebilir.

Anahtar Kelimeler: Hasta yakını, öfke ifade tarzı, psikolojik dayanıklılık, ruh sağlığı

\section{ABSTRACT}

Objective: It is difficult living and taking care with a mentally ill patient for carers. In this study, it was aimed to to examining the relationship between psychological resilience and anger, anger expression styles, sociodemographic variables and life events such as exposure to violence at the relatives of the patients who received psychiatric treatment.

Materials and Methods: The study was conducted with the participation of 200 relatives of hospitalized and outpatients treated at the psychiatry clinics (Female, Male Psychiatric Clinics) of a Training and Research Hospital between the dates of 13 February and 3 April 2017. Data was collected with Personal Information Form, Resilience Scale (RS) and State-Trait Anger Scale (STAS).

Results: It is found that men have significantly higher anger expression scores compared to women. The mean RS and anger control scores of those who have been subjected to violence previously are lower compared to others, and the state anger, anger expression and introverted anger scores are higher. A positive relationship is found between RS and anger control scores $(p<0.05)$.

Conclusions: Our study showed that sex of the relatives of psychiatric patients played a role in their anger expression style, previous subjection to violence was effective in terms of anger management, resilience against difficulties and anger expression style of the individual in subsequent periods, and that individuals with higher anger control have higher resilience at the same time.

Keywords: Anger expression style, mental health, patient's relatives, psychological resilience
Sorumlu Yazar / Corresponding Author:

Bedia Tarsuslu

Sakarya Üniversitesi, Sağlık Bilimleri Fakültesi, Hemşirelik Bölümü, Psikiyatri Hemşireliği ABD. Sakarya Üniversitesi Esentepe Kampüsü, Serdivan, SAKARYA, TÜRKIYE

Tel: +905445166513

E-mail: tarsuslubedia@gmail.com, bediatarsuslu@sakarya.edu.tr
Yayın Bilgisi / Article Info:

Gönderi Tarihi/ Received: 01/09/2020

Kabul Tarihi/ Accepted: 09/09/2020

Online Yayın Tarihi/ Published: 30/09/2020 
*Atıf / Cited: Durat G. et al. Ruhsal bozukluğu olan bireye sahip ailelerin psikolojik dayanma güçleri ile öfke ve öfke ifade tarzlarının incelenmesi. Online Türk Sağllk Bilimleri Dergisi 2020;5(3):519-527. doi: 10.26453/otjhs.788933

*Bu araştırma, “3. Uluslararası Farklı Şiddet Boyutları ve Toplumsal Algı Kongresi, 17-15 Nisan 2017, Kocaeli, Türkiye”de Sözel-özet bildiri olarak sunulmuştur.

\section{Gíriş}

Bireylerin yaşam boyu karşılaşacağı sıkıntıları ve riskleri önlemek güçtür. Ancak bu sıkıntılar, riskler karşısına donanımlı ve güçlü bir şekilde çıkmaları kendini toparlama gücü özelliklerinin geliştirilmesine ve güçlendirilmesine bağlıdır. ${ }^{1}$ Psikolojik dayanıklılık, zor yaşamsal tecrübeler karşısında kişinin kendisini toparlama gücü ${ }^{2}$ veya değişimin ya da felâketlerin başarılı biçimde üstesinden gelme yeteneği olarak tanımlanmaktadır. ${ }^{3}$ Tanımlara bakıldığında, kendini toparlama gücü dinamik bir süreçtir, geliştirilebilir özellikler içerir. ${ }^{1}$

Öfke, günlük hayatımızda önemli yere sahip, evrensel bir duygudur. Bireyler öfke duygusunu planları, istekleri engellendiğinde, haksızlık ve benliklerine yönelik tehdit algıladıklarında yaşarlar. Spielberger ve ark. öfkeyi, basit bir "sinirlilik" veya "kızgınlık" halinden, yoğun "hiddet" durumuna kadar değişen duygusal bir durum olarak tanımlamaktadır. ${ }^{4}$ Genellikle olumsuz bir şekilde ifade edilmesi, olumsuz bir duygu olarak tanınmasına neden olmaktadır. ${ }^{5}$

Bireyler öfke duygularını içe atma, dışa yöneltme ve kontrol etme biçiminde deneyimlemekte ve yansitmaktadırlar. İçe atma, öfkeyi baskı altında tutma ve ifade etmeme; dişa yöneltme, çeşitli fiziksel veya sözel yollarla ifade etmedir. Öfkenin kontrol edilmesi ise, bireyin başkalarıyla olan ilişkilerinde genelde sabırlı, soğukkanlı, hoşgörülü, anlayışlı davranması, çoğu zaman öfkesini kontrol etme ve sakinleşme eğilimi içinde olmasıdır. ${ }^{6,7}$ Öfkenin, tehdit durumunda benlik saygısını ve egonun zarar görmesini engellemesi bakımından koruyucu ve uyum sağlayıcı bir rolü vardır. ${ }^{5}$ Öte yandan, öfke kontrol edilemediği zaman birçok probleme yol açar.

Ruhsal bozukluk tanısı olan bireylerin aile üyeleri, hastalık belirtileri ile başa çıkmada güçlükler yaşamaktadırlar. Psikiyatrik bozukluğu olan bireylerde, atak dönemlerinde sık olarak öfke ve saldırganlık davranışları görülmektedir. Hastaların yakınları öfkeye maruz kaldıkları ve kendi öfke duygularının üstesinden gelmeye çalıştıkları için zorluklar yaşamaktadırlar. ${ }^{8}$ Şizofreni gibi kronik bir ruhsal bozukluk tanısı olan hastaların ailelerinin yüksek duygu dışa vurumu sergiledikleri durumlarda, alevlenmelerin daha sık olduğu gözlenmiştir. ${ }^{9}$ Duygu dişa vuru- mu düşük olan hastaların ailelerinde hastanın kötüleştiği ve aile üyelerinin yüksek duygu dışa vurumu sergilediği durumlarda, tükenmişlik duygusunun daha fazla olduğu görülmektedir. ${ }^{10}$ Ayrıca aile üyeleri arasında depresyon, ${ }^{11}$ çaresizlik, geleceğe yönelik kayg1, güçsüzlük, korku ve öfke gibi duygular da deneyimlenmektedir. ${ }^{12}$ Aileler hem hasta ile hem de kendi duyguları ile baş etmek zorunda kalmaktadır. ${ }^{13}$ Aile üyeleri bu olumsuz duygularla başetmede; durumu kabul etme, felaketleştirme, ruminasyon veya düşüncelere odaklanma gibi baş etme tarzlarını kullanmaktadır. ${ }^{14}$

Ruhsal bozukluğu olan bireylerin yakınları öfke duygusu ile başa çıkma, kişilerarası ilişkiler gibi konularda ciddi zorluklar yaşamaktadır. Bu bağlamda araştırmanın amaci; ruhsal bozukluğu olan hasta yakınlarının, psikolojik dayanma güçleri ile öfke ve öfke ifade tarzlarının, sosyo-demografik değişkenler ve şiddete maruz kalma gibi yaşam olayları arasındaki ilişkinin incelenmesidir. Araştırma, psikiyatrik bozukluğu olan hastaların yakınlarının bilgilendirilmesi ve eğitiminde sorumlu olan sağlık profesyonellerine, bakım vericilerin öfkelerini ifade edebilme, yönetebilme, hastalarıyla daha etkili iletişim kurabilmeleri konusunda yol gösterici olacaktır.

\section{MATERYAL VE METOT}

ISslem: Veriler, 13 Şubat- 3 Nisan 2017 tarihleri arasında sözlü ve yazılı onamları alındıktan sonra psikiyatri kliniği ziyaret salonlarında bire bir hastaların yakınları ile görüşülerek toplanmıştır. Araştırmaya, Sakarya Üniversitesi Tıp Fakültesi Girişimsel Olmayan Araştırmalar Etik Kurulu onayı ve kurum izinleri alındıktan sonra başlanmıştır (Tarih: 09/02/2017, karar no: 71522473/050.01.04/37). Veri toplama aşamasında Helsinki Bildirgesinde yer alan kurallara uygun olarak hareket edilmiştir.

Örneklem: Tanımlayıcı ve analitik tipte planlanan araştırmanın evrenini bir üniversitenin Eğitim ve Araştırma Hastanesi psikiyatri kliniklerinde yatarak veya ayaktan tedavi gören hastaların yakınları oluşturmaktadır. Evrenden örneklem seçimine gidilmemiş, ulaşılabilen, araştırmaya gönüllü olarak katılmayı kabul eden ve iletişim engeli olmayan 200 hastanın yakını dâhil edilmiştir. 


\section{Veri Toplama Araçları:}

Kişisel Bilgi Formu: Araştırmacı tarafindan hazırlanan Kişisel Bilgi Formu, katılımcıların yaş, cinsiyet, medeni durum, eğitim durumu gibi kişisel bilgilerini ve şiddete yönelik (daha önce şiddet görme durumu, şiddete verilen tepki, şiddet karşısında kendini sorumlu tutuma durumu gibi ifadeler...) ifadelerin yer aldığı maddeleri içermektedir.

Kendini Toparlama Gücü Ölçeği (KTG): Wagnild ve Young tarafından geliştirilen Kendini Toparlama Gücü Ölçeği, bireylerin uyumlarını güçlendiren olumlu bir kişilik özelliği olarak tanımlanan kendini toparlama gücünün düzeyini belirlemektedir. Yedili likert tipi, 24 maddelik kendini değerlendirme türü bir ölçüm aracıdır. Ölçekten alınabilecek en düşük puan 24 , en yüksek puan ise 168 'dir. Yüksek puan kendini toparlama gücü düzeyinin yüksek olduğunu işaret etmektedir. KTG'nin Türkçe geçerlik ve güvenirliği Terzi tarafından gerçekleştirilmiştir. ${ }^{15}$ Çalışmamızda ölçek cronbach alfa değeri 0,89 olarak bulunmuştur.

Sürekli Öfke ve Öfke Iffade Ölçeği (SÖÖTÖ): Spielberger, Jacobs, Russel ve Crane tarafindan (1983) geliştirilen SÖÖTÖ, dörtlü likert tipi, 34 maddeden oluşan bir ölçektir. Ölçeğin ilk on maddesi sürekli öfke düzeyini ölçerken, diğer yirmi dört madde ise bireylerin öfke ifade etme tarzlarını belirlemektedir. Öfke ifade tarzları öfke içe vurumu, öfke dışa vurumu ve öfke kontrolü olmak üzere üç alt boyuttan oluşmaktadır. Sürekli öfke alt ölçeğinden alınan yüksek puanlar, öfke düzeyinin yüksek olduğunu, öfke ifade tarzlarından; öfke içe vurum alt boyutundan alınan yüksek puanlar öfkenin bastırıldığını, öfke dışa vurum alt boyutundan alınan yüksek puanlar öfkenin kolayca ifade edilebildiğini, öfke kontrolü alt boyutundan alınan yüksek puanlar ise öfkenin kontrol edilebildiğini göstermektedir. SÖÖTÖ’nün Türkçe'ye uyarlama çalışması Özer tarafından yapılmıştır. ${ }^{6}$ Çalışmamızda ölçek cronbach alfa değerleri 0,61-0,91 arasında değişmektedir.

Verilerin Analizi: Veriler, bilgisayar ortamında SPSS 20 veri analiz programına aktarılarak değerlendirildi. Araştırma verileri değerlendirilirken kategorik değişkenler için frekans dağılımı, sayısal değişkenler için tanımlayıcı istatistikler (ortalama, standart sapma) kullanıldı. Sürekli verilerin normal dağılıma uyup uymadığı Kolmogorov-Smirnov testiyle sınandı ve veriler normal dağılıma uymadığ için ikili grupların karşılaştırılmasında Mann Whitney U testi, üç ve daha fazla grubun karşılaştırılmasında Kruskal Wallis testi, değişkenlerin birbiri ile ilişkilerini belirlemede Spearman korelasyon testi kullanıldı. İstatistiksel anlamlılık için $\mathrm{p}<0,05$ kabul edildi.

\section{BULGULAR}

Araştırmaya katılan bireylerin sosyo-demografik özelliklerine göre dağılımları Tablo 1'de verilmiştir. Hastaların yakınlarının \%46,5'i kendini sakin, \% 38,5'i açık sözlü, \%12'si içine kapanık, \%22,5'i çabuk sinirlenip parlayan, \%7,5'i sorunları önemsemeyen, \%6,5'i sık sık tartışmaya giren bir kişi olarak değerlendirmiştir.

Katılımcıların \%35'i daha önce şiddete maruz kaldığını bildirmiştir. Bunların \%29'u fiziksel, \%1'i cinsel, \%9'u duygusal, \%13,5'i sözel ve \%2,5'i ekonomik şiddete maruz kalmıştır. Ayrıca \%20'si anne ve/ veya babası tarafindan sistematik şiddete maruz b1rakıldıklarını, \%84'ü şiddet gördüğü sürenin 1 yıl ve daha az olduğunu, \%4'ü ise gördükleri şiddetin hala devam ettiğini belirtmiştir. Şiddet görenlerin \% 11,5'i gördüğü şiddetten kendini sorumlu tutmakta, $\%$ 13'ü ise kendini suçlamaktadır. Şiddete maruz kalanların \%27,5'i şiddet karşısında polisi aradığını, \%17,5'i aynı şekilde karşılık verdiğini, \%48'i kendini savunduğunu, \%18'i ise kabullenip sessiz kaldığ1nı ifade etmiştir. Bireyler "Şiddet uygulanan birini gördüğünüzde ne yaparsınız?" sorusuna, $\% 45$ 'i “polisi ararım”, \%41,5'i “müdahale ederim”, \%20'si ise "karışmam" yanıtını vermiştir.

Sosyo-demografik özelliklere göre KTG puan ortalamaları karşılaştırıldığında, cinsiyete göre KTG puan ortalamaları arasında anlamlı bir farklılık görülmezken, geniş aileye sahip olanların KTG puan ortalamalarının, çekirdek aileye sahip olanlara göre anlamlı bir şekilde daha yüksek olduğu saptanmıştır $(p<0,05)$. Ayrica daha önce şiddete maruz kalanların, kalmayanlara göre KTG $(\mathrm{MWU}(\mathrm{Z})=3,637$; $\mathrm{p}=0,019)$ puan ortalamaları daha düşük bulunmuştur (Tablo 2).

Katılımcıların özelliklerine göre SÖÖTÖ puan ortalamaları karşılaştırıldığında, erkeklerin kadınlara göre öfke dışa vurum puan ortalamaları anlamlı derecede daha yüksektir $(\mathrm{MWU}(\mathrm{Z})=-2,735 ; \mathrm{p}=0,006)$. Daha önce şiddete maruz kalanların, kalmayanlara göre SÖÖTÖ öfke kontrol boyutu $(\mathrm{MWU}(\mathrm{Z})=$ $2,010 ; p=0,044)$ puan ortalamaları daha düşük, sürekli öfke $(\mathrm{MWU}(\mathrm{Z})=-2,567 ; \mathrm{p}=0,010)$, öfke dişa vurum $(M W U(Z)=-2,483 ; p=0,013)$ ve öfke içe vurum $(\mathrm{MWU}(\mathrm{Z})=-2,293 ; \mathrm{p}=0,022)$ alt boyut puan ortalamaları daha yüksektir (Tablo 2).

Katılımcıların KTG, SÖÖTÖ sürekli öfke ve öfke ifade tarzları alt boyutları puan ortalamaları ve ölçekler arasındaki korelasyon sonuçları Tablo 3'de 
verilmiştir. KTG ölçeği ile SÖÖTÖ öfke kontrol alt boyutu arasında pozitif yönde ilişki bulunmuştur $(\mathrm{r}=0,28 ; \mathrm{p}=0,00)$.

\section{TARTIŞMA VE SONUÇ}

Kronik ruhsal hastalığı olan bireylerin aileleri bakım verme rollerini yerine getirirken, endişe umutsuzluk, utanç, korku, anksiyete vb. sorunlar yaşamaktadır. ${ }^{9}$ Literatürde ruhsal hastalığı olan bireylerin aileleri ile yapılan bazı araştırmalarda katılımcıların çoğunluğunun ebeveyn olduğu görülmektedir. ${ }^{16}$ Bizim araştırmamızda, katılımcıların yaklaşık 1/3'ünü, kardeşler oluşturmuştur. Buna göre, hastaya bakımda eş ve ebeveynle birlikte kardeşlerin de yüksek oranda sorumluluk aldığı söylenebilir.

Kendini toparlayabilme; hastalıkta, depresyonda, değişimlerde ya da benzeri olumsuz durumlarda çabucak iyileşme yeteneği, incindikten, gerildikten sonra eski haline kolayca dönebilme olarak tanımlamaktadır. ${ }^{17}$ Psikiyatrik hastaların yakınlarının psikolojik dayanıklılıkları konusunda gerçekleştirilen bir araştırmada, hastaların erkek yakınlarının dayanıklılıklarının daha yüksek olduğu saptanmıştır. ${ }^{16}$ Connor ve Davidson'un araştırmasında, kaygı ve depresif bozuklukları olan bireylerin dayanıklılık puanlarının da düşük olduğu bildirilmektedir. ${ }^{18}$ Bizim araştırmamızda, cinsiyet açısından KTG puan ortalamalarında istatistiksel olarak bir farklılık görülmemiştir. Katılımcıların büyük çoğunluğunun ruhsal açıdan sağlı11 olduğu dikkate alındığında, cinsiyete göre KTG puanlarında farklılık görülmemesi, ruhsal açıdan KTG'lerini etkileyecek düzeyde bir sorun yaşamamalarına bağlanabilir.

Araştırmamızda katılımcılardan çekirdek aileye göre, geniş aileye sahip olanların KTG puan ortalamaları daha yüksek bulunmuştur. Bizim çalışmamızla benzer biçimde, Güngörmüş, Okanlı ve Kocabeyoğlu'nun psikolojik dayanıklılığı etkileyen faktörleri incelendikleri çalışmada, psikolojik dayanıklılık ile aile ve arkadaştan algılanan sosyal destek arasında güçlü bir ilişki olduğu saptanmıştır. ${ }^{19}$ Buna göre geniş aileye sahip olanların KTG'lerinin daha yüksek olması, diğer aile bireylerinden aldıkları sosyal destekle ilişsilendirilebilir.

Ruhsal bozukluğu olan ve davranışlarını kontrol edemeyen hastaya bakım vermek, hastaların yakınlarının kendini toparlama güçlerini etkilemesinin yanı sıra yoğun bir şekilde öfke duygusu yaşamasına neden olabilir. ${ }^{20}$ Hastaların yakınları kendilerini suçlu hissedebilir, geçici/sürekli öfke duygusu yaşayabilirler. Hastanın bazı hareketleri onları öfkelendirebilir ve bu öfkeyi diğer aile fertlerine yansitabilir- ler. ${ }^{21}$ Literatüre baktığımızda ruhsal bozukluğu olan hastaların yakınlarından, bazı aile üyelerinin hastaya zarar vermemek veya kırmamak için öfkelerini bastırdıkları ve kendilerine yönelttikleri, bazılarının ise kızdığı, bağırdığı ya da kendini/diğer aile üyelerini suçladıkları görülmektedir. ${ }^{22}$ Hastaların şiddet gören yakınlarının \%11,5'inin gördüğü şiddetten kendini sorumlu tuttuğu, \%13'ünün ise gördüğü şiddet nedeniyle kendini suçladığı bulgusu, katılımcıların yaklaşı 1/4 ünün hissettikleri öfkeyi bastırdıklarını ve kendilerine yönelttiklerini düşündürmektedir.

Şiddete maruz kalmanın psikolojik sağlamlık/ dayanıklılık için risk faktörlerinden olduğu bildirilmektedir. ${ }^{23}$ Daha önce şiddete maruz kalmayanların KTG ve öfke kontrol puanlarının, kalanlara göre daha yüksek olması, kalmayanların dayanıklılıklarının daha güçlü olduğunu ve öfkelerini kontrol etme çabası içinde olduklarını göstermektedir. Sürekli öfke deneyimleyen birey, yaşamında birçok durum/ olayı engelleyici, can sıkıcı algılamakta bunun sonucu olarak sıklıkla sürekli öfke duygusu yaşamaktadır. ${ }^{6,7}$ Arslan araştırmasında, kendine güvensiz yaklaşım arttıkça öfkenin içe ve dışa vurumunun, sürekli öfke yaşamanın arttığını, problem odaklı başa çıkma arttıkça sürekli öfkenin azaldığını bulmuştur. ${ }^{4}$ Aile içinde şiddete maruz kalan veya tanık olan bireylerin, ebeveynlerinin öfke ifade tarzlarını öğrendikleri dikkate alındığında ${ }^{24}$ daha önce şiddete maruz kalanların sürekli öfke, öfke dışa ve öfke içe vurum puanlarının, kalmayanlara göre istatistiksel olarak yüksek olması literatür ile uyumludur. $\mathrm{Bu}$ bulgu, daha önce şiddete maruz kalanların olumsuz olay/durum karşısında hissettikleri öfkeyi bastırdıklarını, ifade edemediklerini, edenlerin ise etkin olmayan biçimde kolayca dışa yansıttıklarını düşündürmektedir.

Toplumun en küçük ve temel birimi olan aile üyeleri birbirleriyle biyolojik olarak bağlı olmanın yanında psikolojik, sosyolojik olarak ilişki içinde ve birbirlerine karşı sorumlulukları olan bireylerden oluşmaktadır. ${ }^{22}$ Ruhsal bozukluğu olan bireye bakım vermede aile üyeleri birincil derecede sorumluluk almaktadır. Lauber ve ark.'nın araştırmasında, şizofreni hastalarına bakım verenlerin öznel ve nesnel bir yük yaşadıkları ve bunların yarıdan fazlasının öfkeyle başa çıkmaya çalıştıkları bildirilmiştir. ${ }^{25}$ SÖÖTÖ'yü kullanarak şizofreni hastalarının yakınları ile gerçekleştirilen başka bir araştırmada, bakım verilen sürenin, bakım verilen kişinin bağımlılık, duygusal, sosyal yükleri ve bakım verenin fiziksel yükü ile öfke düzeyleri arasında ilişki olduğu saptanmıştır. ${ }^{26} \mathrm{Bu}$ araştırmada, öfke kontrol alt boyut puan ortalaması 
$(28,05 \pm 5,57)$, bizim araştırmamıza göre daha yüksek bulunmuştur $(22,77 \pm 5,38)$. Bu, şizofreni gibi kronik bir ruhsal bozuklukta bakım verenlerin, süreç içerisinde hastalarının semptomlarını kontrol edemediklerini kabul etmelerine, ${ }^{27}$ iyimser yaklaşım, kendine güvenli yaklaşım gibi baş etme yöntemlerini kullanabilmeye başlamalarına, ${ }^{28}$ hastalarına bakım konusunda deneyim kazanmalarına ve öfkelerini daha fazla kontrol edebilmelerine bağlanabilir. Araştırma sonuçlarındaki farklılık bizim araştırmamızdaki örneklem grubunun, şizofreniye ek olarak, depresyon ve bipolar tanılı hastaların yakınlarından oluşması ile ilişkilendirilebilir. Ünal ve ark.'nın yaptığı araştırmada bipolar bozukluğu olan hastaların yakınlarının genel işlevsellik düzeyinin, şizofreni hastalarının ailelerine göre daha iyi olduğu bulgusu da bu sonucu destekler niteliktedir. ${ }^{29}$ Ruhsal hastalıkların şiddeti/süresi/tipi ve hastaların yakınlarının öfke kontrol becerileri ile ilgili daha ileri çalışmalara gereksinim vardır.

Öfkenin kontrol edilmesi kişinin başkalarıyla ilişkilerinde sabırlı, soğukkanlı, anlayışlı davrandığını, çoğunlukla sakinleşme eğiliminde ve öfkesini kontrol etme çabası içerisinde olduğunu göstermektedir. ${ }^{7}$ Arslan, kişilerarası ilişkiler, stresle başa çıkma ile öfke ifade biçimlerini incelediği araştırmada, problem odaklı başa çıkma, ısrarcı-sebatkâr yaklaşım ve öfke kontrolü arasında pozitif ilişki olduğunu saptamıştır. ${ }^{4}$ Araştırmamızda, katılımcıların yarısına yakınının kendini sakin olarak tanımlaması, kendini toparlama güçleri arttıkça öfke kontrol güçlerinin de arttığını, kendini toparlama gücünün yüksek olması bireylerin öfke duygularıla problem odaklı başa çıkmaya çalıştıklarını ve ısrarcı sebatkâr bir yaklaŞım içinde olduklarını düşündürmektedir.

Sonuç olarak; Psikiyatrik hastalıklarda eş ve ebeveynin yanında kardeşlerin de büyük oranda sorumluluk aldığı, geniş aileye sahip olanların kendini toparlama güçlerinin, çekirdek aileye sahip olanlara göre daha yüksek olduğu belirlenmiştir. Ayrıca daha önce şiddete maruz kalmanın zorluklar karşısında baş edebilme, kişinin öfkesini ifade ediş biçimi ve öfke kontrolü üzerinde etkili olduğu, kendini toparlama gücü iyi olan bireylerin, öfke kontrollerinin de yüksek olduğu söylenebilir. Bu sonuçların, hasta yakınlarının, hastalarıyla kuracakları ilişkide yaşadıkları zorlukların üstesinden gelebilmede, olumsuz öfke duygularına karşı etkili başa çıkma yöntemlerini kullanabilmelerine katkı sağlayacağı düşünülmektedir. Çalışmanın deneysel bir çalışma olmaması, değişkenlerin sadece araştırmada kullanılan ölçüm araçla- r1 ile değerlendirilmesi ve tek bir merkezde gerçekleştirilmesi bu araştırmanın sınırlılıklarıdır.

Etik Komite Onayı: Çalışmamız Sakarya Üniversitesi Tıp Fakültesi Girişimsel Olmayan Araştırmalar Etik Kurulu (Tarih:09/02/2017, Karar no: 71522473/050.01.04/37) tarafindan onayland1.

Çıkar Çatışması: Yazarlar çıkar çatışması bildirmemişlerdir.

Yazar Katkıları: Fikir -GD, GDÇ, ZE; Veri toplanması ve/veya işlemesi - AE, ZE, MK; Analiz ve/ veya yorum - GD, GDÇ, BT; Yazıyı yazan - GD, BT.

Hakem Değerlendirmesi: Dış bağımsız.

\section{REFERENCES}

1. Işık Ş. Türkiye'de kendini toparlama gücü konusunda yapılmış araştırmaların incelenmesi. Türk PDR Dergisi. 2017;7(47):117-34.

2. Garmezy N. Resiliency and vulnerability to adverse developmental outcomes associated with poverty. Am Behav Sci. 1991;34(4):416-430.

3. Wagnild GM, Young HM. Development and psychometric evaluation of the resilience scale. $\mathrm{J}$ Nurs Meas. 1993;1(2):165-178.

4. Arslan C. öfke ve öfkeyi ifade etme biçimlerinin, stresle başa çıkma ve kişiler arası problem çözme açısından incelenmesi. Kuram ve Uygulamada Eğitim Bilim. 2010;10(1):7-43.

5. Cüceloğlu D. İnsan ve Davranışı: Psikolojinin Temel Kavramları. 14th ed. Remzi Kitabevi A.Ş. İstanbul; 2005.

6. Özer KA. Sürekli öfke (SL-Öfke) ve öfke ifade tarzı (Öfke-Tarz) ölçekleri ön çalışması. Turk Psikol Derg. 1994;9(31):26-35.

7. Spielberger C, Crane R, Kearns W, Pellegrin K, Rickman R, Johnson E. Anger and anxiety in essential hypertension. Stress and Emotion. 1991;14:265-283.

8. Eser Taşçı D, Üstün B. Psikiyatrik bozukluğu olan ergen ve ebeveynlerinin öfke ifade biçimleri arasındaki ilişkinin incelenmesi. J Psychiatr Nurs. 2011;2:111-116.

9. Gülseren L. Şizofreni ve aile: Güçlükler, yükler, duygular, gereksinimler. Türk Psikiyatr Derg. 2002;13(2):143-151.

10. Nirmala B, Reddy S, Vranda M. Expressed emotion and caregiver burden in patients with schizophrenia. Indian J Psychol Med. 2011;33(2):119122. 
11. Saunders JC. Families living with severe mental illness: A literature review . Ment Health Nurs. 2003;24(2):175-198.

12. Rowaert S, Vandevelde S, Lemmens $G$, et al. The role and experiences of family members during the rehabilitation of mentally ill offenders. Int J Rehabil Res. 2016;39(1):11-19.

13. Karanci AN. Caregivers of Turkish schizophrenic patients: causal attributions, burdens and attitudes to help from the health professionals. Soc Psychiatry Psychiatr Epidemiol. 1995;30:261268.

14. Rowaert S, Vandevelde S, Audenaert K, Lemmens G. Family support groups for family members of mentally ill offenders: a pilot study. J Forensic Psychiatry and Psychol. 2018;29(5):762 -773 .

15. Terzi Ş. Kendini toparlama gücü ölçeği'nin uyarlanması: geçerlik ve güvenirlik çalışmaları. Türk PDR Derg. 2006;3(26):77-86.

16. Aloba O, Ajao O. Exploration of the psychometric properties and correlates of the 10 item connor-davidson resilience scale among family caregivers of nigerian patients with psychiatric disorder. Int J Ment Heal Psychiatry. 2016;02(03):1-8.

17. Earvolino-Ramirez M. Resilience: A concept analysis. Nurs Forum. 2007; 42(2):73-82.

18. Connor KM, Davidson JRT. Development of a new resilience scale: the connor-davidson resilience scale (CD-RISC). Depression and Anxiety. 2003;18(2):76-82.

19. Güngörmüş K, Okanlı A, Kocabeyoğlu T. Hemşirelik öğrencilerinin psikolojik dayanıklılıkları ve etkileyen faktörler. Psikiyatr Hemşireliği Derg. 2015;6(1):9-14.

20.Karp DA, Tanarugsachock V. Mental illness, caregiving, and emotion management. Qual Health Res. 2000;10(1):6-25.

21. Doğan S, Doğan O, Tel H, Çoker F, Polatöz Ö, Başeğmez F. Şizofrenide psikososyal yaklaşımlar: Ayaktan hastalar. Anadolu Psikiyatr Derg. 2002;3(2):69-74.

22. Köroğlu A, Hocaoğlu Ç. Şizofreninin aile üzerine olan etkisi. DÜ Sağlık Bil Enst Derg. 2017;7(3):170-175.

23. Çetin I, Altıntaş M. Aile içi şiddet mağduru kadınlarda ruhsal dayanıklılık, bağlanma biçimleri, başa çıkma tutumları ve psikopatoloji. Anadolu Psikiyatr Derg. 2017;18(6):561-570.
24. Wolf KA, Foshee VA. Family violence, anger expression styles, and adolescent dating violence. J Fam Violence. 2003;18(6):309-316.

25.Lauber C, Eichenberger A, Luginbühl P, Keller C, Rössler W. Determinants of burden in caregivers of patients with exacerbating schizophrenia. Eur Psychiatry. 2003;18(6):285-289.

26. Bademli K, Lök N, Kılıc AK. Relationship between caregiving burden and anger level in primary caregivers of individuals with chronic mental illness. Arch Psychiatr Nurs. 2017;31(3):263268.

27. Karanci AN, Inandilar H. Predictors of components of expressed emotion in major caregivers of Turkish patients with schizophrenia. Soc Psychiatry Psychiatr Epidemiol. 2002;37(2):80-88.

28. Şengün F. Şizofreni Hastasına Bakım Verenlerin Ruhsal Sağlık Durumlarını Etkileyen Etmenlerin İncelenmesi.Yayınlammaış Yüksek Lisans Tezi, İzmir, Dokuz Eylül Üniversitesi Sağlık Bilimleri Enstitüsü Psikiyatri Hemşireliği ABD, 2007.

29. Ünal S, Kaya B, Çekem B, Özişik HI, Çakil G, Kaya M. Şizofreni, iki uçlu duygudurum bozukluğu ve epilepsi hastalarında aile işlevlerinin karşılaştırılması. Türk Psikiyatr Derg. 2004;15 (4):291-299. 
Tablo 1. Sosyo-demografik özellikler.

\begin{tabular}{|c|c|c|c|}
\hline & $\overline{\mathbf{X}} \pm \mathbf{s d}$ & Min & Max \\
\hline \multirow[t]{2}{*}{ Yaş } & $42,25 \pm 15,54$ & 18 & 89 \\
\hline & $\mathbf{n}$ & Yüzde (\%) & \\
\hline \multicolumn{4}{|l|}{ Cinsiyet } \\
\hline Kadın & 90 & 45 & \\
\hline Erkek & 110 & 55 & \\
\hline \multicolumn{4}{|l|}{ Medeni durum } \\
\hline Evli & 146 & 73 & \\
\hline Bekâr & 53 & 27 & \\
\hline \multicolumn{4}{|l|}{ Eğitim durumu } \\
\hline $\begin{array}{l}\text { Okuryazar } \\
\text { değil }\end{array}$ & 17 & 8,5 & \\
\hline $\begin{array}{l}\text { İlkokul/ } \\
\text { ortaokul }\end{array}$ & 90 & 45 & \\
\hline Lise & 53 & 26,5 & \\
\hline $\begin{array}{l}\text { Üniversite ve } \\
\text { üstü }\end{array}$ & 40 & 20 & \\
\hline \multicolumn{4}{|l|}{ Sağlık durumu } \\
\hline Fiziksel engel & 17 & 8,5 & \\
\hline $\begin{array}{l}\text { Kronik fiziksel } \\
\text { hastalık }\end{array}$ & 36 & 18 & \\
\hline Ruhsal hastalık & 12 & 6 & \\
\hline \multicolumn{4}{|c|}{ Hastaya yakınlık derecesi } \\
\hline Eşi & 37 & 18,5 & \\
\hline Annesi & 21 & 10,5 & \\
\hline Babas1 & 15 & 7,5 & \\
\hline Çocuğu & 48 & 24 & \\
\hline Kardeşi & 60 & 30 & \\
\hline \multicolumn{4}{|l|}{ Hastanın tanısı } \\
\hline $\begin{array}{l}\text { Psikoz- } \\
\text { şizofreni }\end{array}$ & 38 & 19 & \\
\hline Bipolar & 146 & 73 & \\
\hline Depresyon & 16 & 8 & \\
\hline
\end{tabular}




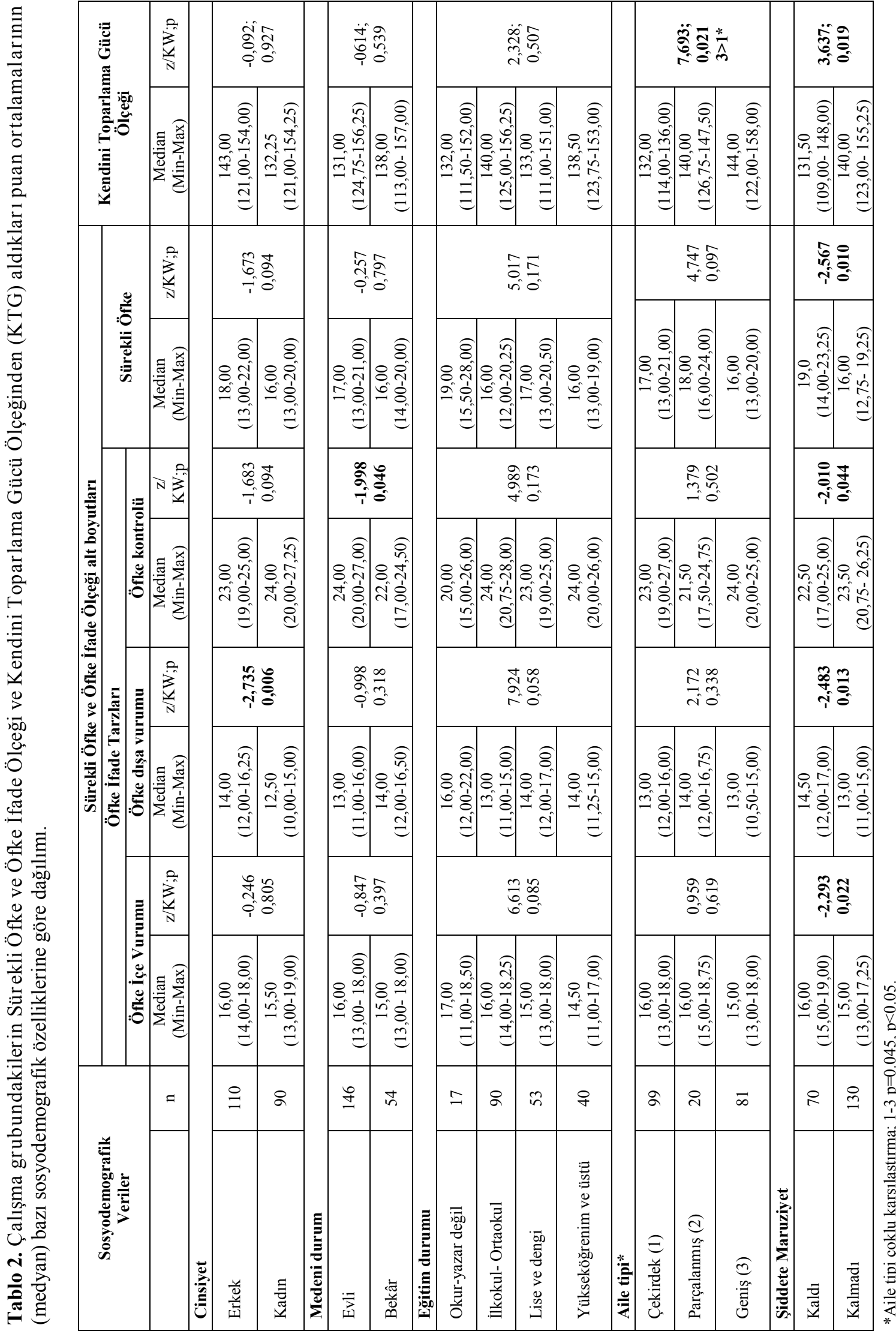


Tablo 3. Kendini toparlama gücü ölçeği (KTG) ve sürekli öfke ve öfke ifade ölçeği (SÖÖTÖ) alt boyutları korelasyon sonuçları, $\overline{\mathrm{x}} \pm \mathrm{Sd}$ ve Conbach Alpha değerleri.

\begin{tabular}{|l|c|c|c|c|c|c|c|}
\hline \multicolumn{1}{|c|}{ Ölçek } & $\mathbf{1}$ & $\mathbf{2}$ & $\mathbf{3}$ & $\mathbf{4}$ & $\mathbf{5}$ & $\overline{\mathbf{x}} \pm$ Sd & $\begin{array}{c}\text { Conbach } \\
\text { Alpha }\end{array}$ \\
\hline $\begin{array}{l}\text { Kendini Toparlama Gücü } \\
\text { Ölçeği }\end{array}$ & 1 & $\mathbf{0 , 0 0 0 *}$ & 0,589 & 0,201 & 0,833 & $134,01 \pm 24,89$ & 0,89 \\
\hline Öfke kontrol & & 1 & $0,000^{*}$ & 0,158 & $0,000^{*}$ & $22,77 \pm 5,38$ & 0,91 \\
\hline Öfke dişa vurum & & & 1 & $0,001^{*}$ & $0,000^{*}$ & $13,97 \pm 4,19$ & 0,78 \\
\hline Öfke içe vurum & & & & 1 & $0,000^{*}$ & $15,77 \pm 3,82$ & 0,61 \\
\hline Sürekli öfke & & & & & 1 & $17,68 \pm 5,88$ & 0,87 \\
\hline
\end{tabular}

*Spearman korelasyon testi, $\mathrm{p}<0.05$. 